Journal of

Molecular Microbiology

and Biotechnology

\title{
Genetic Evidence for a TatC Dimer at the Core of the Escherichia coli Twin Arginine (Tat) Protein Translocase
}

\author{
Barbara Maldonado $^{a} \quad$ Grant Buchanan $^{a}$ Matthias Müller ${ }^{c}$ Ben C. Berks ${ }^{b}$ \\ Tracy Palmer ${ }^{\mathrm{a}}$ \\ ${ }^{a}$ Division of Molecular Microbiology, College of Life Sciences, University of Dundee, Dundee, and ${ }^{\mathrm{b}}$ Department of \\ Biochemistry, University of Oxford, Oxford, UK; ' Institute of Biochemistry and Molecular Biology, ZBMZ, \\ Freiburg, Germany
}

\section{Key Words}

Protein transport $\cdot$ Twin arginine signal peptide $\cdot$ Tat

pathway $\cdot$ TatBC complex $\cdot$ Dimer $\cdot$ Genetic fusion

\begin{abstract}
The twin arginine protein transport (Tat) system transports folded proteins across the cytoplasmic membranes of prokaryotes and the thylakoid membranes of plant chloroplasts. In Escherichia coli, the TatB and TatC components form a multivalent receptor complex that binds Tat substrates. Here, we have used a genetic fusion approach to construct covalent TatC oligomers in order to probe the organisation of TatC. A fused dimer of TatC supported Tat transport activity and was fully stable in vivo. Inactivating point mutations in one or other of the TatC units in the fused TatC dimer did not inactivate TatC function, indicating that only one TatC protomer in the TatC fused dimer needs to be active. Larger covalent fusions of TatC also supported Tat transport activity but were degraded in vivo to release smaller TatC forms. Taken togeth$\mathrm{er}$, these results strongly suggest that TatC forms a functional dimer, and support the idea that there is an even number of TatC protomers in the TatBC complex.
\end{abstract}

Copyright $\odot 2011$ S. Karger AG, Basel
Protein transport across the bacterial cytoplasmic membrane and the thylakoid membrane of plant chloroplasts is achieved by one of two general pathways. The Sec (general secretory) pathway exports proteins in an unfolded conformation, powered by SecA-mediated ATP hydrolysis and the protonmotive force $(\Delta p)$ [Driessen and Nouwen, 2008]. By contrast, the twin arginine protein transport (Tat) pathway transports folded proteins across the membrane, driven solely by $\Delta p$ [Cline and Theg, 2007; Muller, 2005; Palmer et al., 2010]. Proteins are targeted to the Sec and Tat pathways by cleavable N-terminal signal peptides that share similar features; however, Tat signal peptides harbour a conserved twin arginine motif which is essential for recognition by the Tat machinery [Berks, 1996; Stanley et al., 2000].

In Gram-negative bacteria such as Escherichia coli, the Tat machinery comprises three membrane-bound components, Tat $\mathrm{A}$, TatB and TatC, orthologues of which are also found in plant thylakoids [Bogsch et al., 1998; Mori et al., 2001; Sargent et al., 1998, 1999; Settles et al., 1997; Weiner et al., 1998]. The Tat A protein probably forms the protein-conducting element of the Tat system. It forms large homo-oligomeric ring-like structures that surround central cavities of sufficient dimensions to accom-

\section{KARGER \\ Fax +4161306 1234 E-Mail karger@karger.ch} www.karger.com

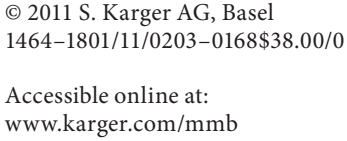

Tracy Palmer

Division of Molecular Microbiology

College of Life Sciences, University of Dundee

Dundee DD1 5EH (UK)

Tel. +44 1382386 464, E-Mail t.palmer@ dundee.ac.uk 
modate folded proteins [Gohlke et al., 2005]. In vivo, large complexes of TatA appear to assemble from tetrameric units in a process which is dependent on the presence of the TatB and Tat $\mathrm{C}$ components [Dabney-Smith et al., 2006; Leake et al., 2008].

The TatB protein shares structural homology with Tat A but has a distinct and essential function in protein export [Sargent et al., 1999]. Together with TatC, it is a component of the TatBC complex where the two constituent polypeptides are present in 1:1 stoichiometry [Bolhuis et al., 2001]. The TatBC complex acts as a receptor for Tat substrates, interacting with them primarily through the twin arginine signal peptide, but also making contacts to the mature domain [Alami et al., 2003; de Leeuw et al., 2002; Mori and Cline, 2002; Richter and Bruser, 2005; Tarry et al., 2009; Maurer et al., 2010].

The TatBC complex contains multiple copies of TatB and TatC. The precise stoichiometry of the complex is unknown, but probably contains between 6 and 8 copies of each protein [Bolhuis et al., 2001; Oates et al., 2003; Richter and Bruser, 2005; Tarry et al., 2009]. Disulphide mapping studies have been used to infer that the Tat $B$ component is arranged as a bundle on the interior of the complex, whereas TatC is localised at the periphery [Lee et al., 2006; Punginelli et al., 2007]. Both TatB and TatC can be cross-linked to signal peptides; however, crosslinking of TatC is restricted to the twin arginine motif of the signal peptide [Alami et al., 2003; Gerard and Cline, 2006]. A role for TatC in the recognition of the twin arginine motif is supported genetically by the isolation of mutations in TatC that switch the specificity of transport from signal peptides containing twin arginines to twin lysines [Strauch and Georgiou, 2007].

Recently, it has been shown that the TatBC complex is multivalent. Isolation of the E. coli TatBC complex from cells overproducing the SufI substrate protein followed by analysis by negative stain electron microscopy revealed a proportion of TatBC complexes with two adjacently-bound SufI molecules [Tarry et al., 2009]. Studies of the orthologous complex (Hcf106:cpTatC) from thylakoids show that up to four substrate molecules bound to a single receptor complex can be transported together [Ma and Cline, 2010]. In this system, receptor-bound substrates can be cross-linked to each other through exposed cysteine residues [Ma and Cline, 2010], again suggesting that substrates bind at adjacent sites within the receptor complex.

In this study, we have constructed TatC fusion proteins to address questions relating to the arrangement and stoichiometry of TatC proteins in the TatBC com- plex. Our studies strongly suggest that the functional unit of TatC is a dimer. Moreover, by introducing inactivating point mutations into the individual TatC units of the dimer, we show that only one functional TatC within the dimeric unit is sufficient for Tat transport activity.

\section{A Fused TatC Dimer Is Functional}

The precise number of Tat $\mathrm{B}$ and TatC subunits within the TatBC complex is uncertain. Size analysis of the isolated complex by gel filtration and blue native PAGE estimates between 6 and 8 copies of each protein [Bolhuis et al., 2001; de Leeuw et al., 2002; Oates et al., 2003; Richter and Bruser, 2005; Tarry et al., 2009], with a heptameric arrangement suggested from analysis of substrate-bound TatBC complexes by electron microscopy [Tarry et al., 2009]. Determining the precise stoichiometry of protein complexes is not always straightforward. One way this has been approached is to construct genetic fusions between partner proteins. This methodology was used to infer a 1:1 stoichiometry of $E$. coli TatB and TatC [Bolhuis et al., 2001] and was also used to probe the organisation of the $c$ subunit in the $\mathrm{F}_{\mathrm{o}}$ portion of the E. coli $\mathrm{H}^{+}$-transporting ATPase [Jones and Fillingame, 1998].

We therefore designed a strategy to construct genetic fusions of TatC, utilizing the tat $A B C$ overexpressing vector, pUNITAT2 [McDevitt et al., 2005], where the TatC protein is supplied with a C-terminal hexahistidine tag. An approach was used where any number of tat $C$ genes could be fused together and is based on the premise that the restriction enzymes Bsp120I and Eco52I generate compatible ends which when ligated together results in destruction of both recognition sequences, thus allowing continuous addition of tat $C$ units to the $3^{\prime}$ end. Full details of this strategy are provided in figure 1a.

Initially, we tested out this approach by constructing a covalent TatC dimer. To assess whether the fused TatC dimer was competent to support Tat transport activity, it was coproduced with Tat $\mathrm{A}$ and TatB in a strain lacking chromosomal tat genes, and the activity of trimethylamine- $\mathrm{N}$-oxide (TMAO) reductase, a Tat-exported enzyme, was determined in the periplasmic fraction. It is clear from figure $1 \mathrm{~b}$ that the fusion protein was able to support Tat transport activity. As shown in figure 2, the fused TatC dimer could also support transport of a second Tat substrate, periplasmic nitrate reductase (Nap). Thus, an E. coli tat mutant strain producing Nap as the only nitrate reductase showed similar growth kinetics on nitrate-containing medium when either the monomeric 

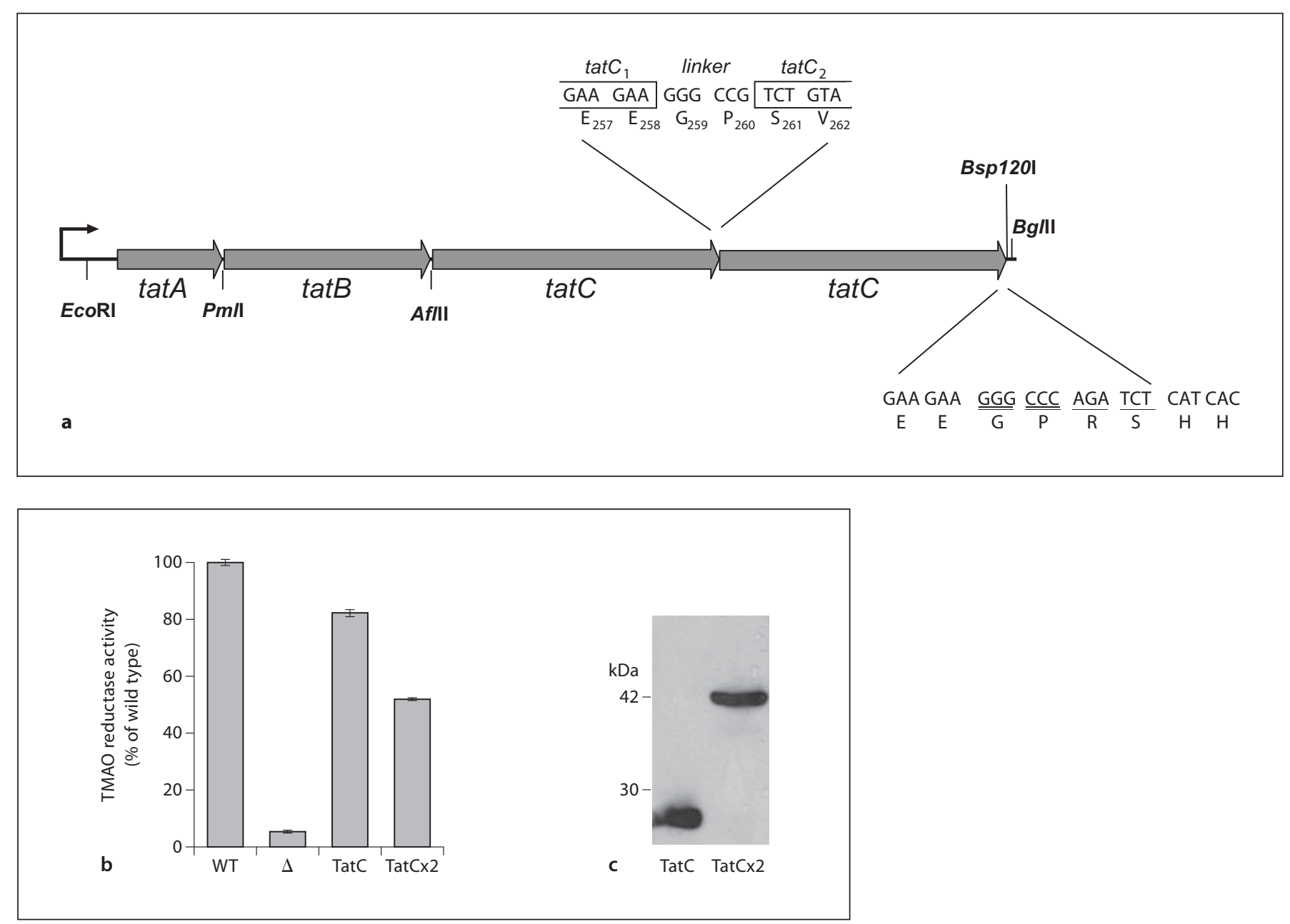

Fig. 1. A covalent dimer of TatC is functional. a Schematic representation of the construct expressing fused dimeric tat $C$. Initially, a starter unit of tatC was cloned into pLitmus28 (New England Biolabs) by amplification with oligonucleotides TatCAflII (GCGCGAATTCCTTAAGCATGTCTGTAGAAGATACT) and TatCadnaus1 (GCGCAGATCTGGGCCCTTCTTCAGTTTTTTCGC) and digestion with EcoRI and BglII, to give pLitmus-TatCstarter. An additive unit of tat $C$ was also cloned into pLitmus 28 following amplification of tatC using oligonucleotides TatCadnaus1 and TatCadnaus2 (GCGCGAATTCCGGCCGTCTGTAGAAGATACTCAACC) and digestion with EcoRI and BglII, to give pLitmus-TatC-buildblock. The tat $C$ gene from pLitmusTatC-starter was excised by digestion with AflII and BglII and cloned into similarly digested pUNITAT2 [McDevitt et al., 2005] to give pUNITAT2-TatC-starter. This construct was digested with Bsp120I and BglII, and the tatC gene from pLitmus-TatCbuildblock was cloned into this as an Eco52I-BglII fragment to give pUNITAT-TatCx 2 . The sequence of the fusion junction between the tandem $\operatorname{tat} C$ genes is shown. The sequence at the $3^{\prime}$ end of the second tatC unit is also shown (with the Bsp120I and BglII restriction sites shown in double and single underline, respec- tively). Additional tat $C$ units can be added sequentially by digestion of the vector with $B s p 120 \mathrm{I}$ and cloning of $t a t C$ units from pLitmus-TatC-buildblock as Eco52I-BglII fragments. Note that the final tat $C$ unit in each fusion is fused to a hexa histidine tagcoding sequence. $\mathbf{b} \mathrm{A}$ fused dimer of TatC has Tat transport activity. Periplasmic TMAO reductase activities (assayed according to the method of Silvestro et al. [1988] from strains cultured anaerobically overnight in LB medium supplemented with $0.5 \%$ glycerol and $0.4 \%$ TMAO) were measured from the periplasmic fraction of the parental strain, MC4100-P (tat ${ }^{+}$[Buchanan et al., 2002]; designated $\mathrm{WT}$ ) or the tat $A B C D E$ deletion strain DADE-P [Lee et al., 2006] carrying either empty pQE60 vector $(\Delta)$, or a plasmid producing TatA, TatB along with monomeric (pUNITAT2; designated TatC) or fused dimeric TatC (from pUNITAT-TatCx2; designated TatCx2). c The fused TatC dimer is stable. Western blot analysis (approximately $2 \times 10^{7}$ cells loaded per lane) of whole cell samples from DADE-P producing TatA, TatB along with either momoneric or fused dimeric TatC grown under identical conditions to $\mathbf{b}$. Samples were separated by SDS PAGE $(10 \%$ acrylamide) and blotted with anti-TatC antiserum [Alami et al., 2002]. 
Fig. 2. The covalent TatC dimer supports export of periplasmic nitrate reductase. Strain SG1100 deltaTat::Apra (as MG1655; $\Delta$ narJ $\Delta$ narW $\Delta$ tat $A B C::$ Apra) harbouring pQE60 (○), pUNITAT2 (๑) or pUNITATTatCx2 $(\triangle)$ was inoculated (at 1:100 dilution) into LB medium supplemented with $0.5 \%$ glycerol and $0.1 \%$ sodium nitrate, and incubated under anaerobic conditions for $12 \mathrm{~h}$. At the indicated time points, samples were withdrawn to measure optical density at $600 \mathrm{~nm}$. At the same time points, the concentration of nitrite present in the growth media was also determined according the method of Lester and DeMoss [Lester and DeMoss, 1971]. Nitrite accumulation is shown as light grey bars for the strain SG1100 deltaTat::Apra harbouring pUNITAT2 and dark grey bars for SG1100 deltaTat::Apra harbouring pUNITATTatCx2. No nitrite was produced for the strain containing pQE60. The error bars represent standard deviation $(\mathrm{n}=3)$.

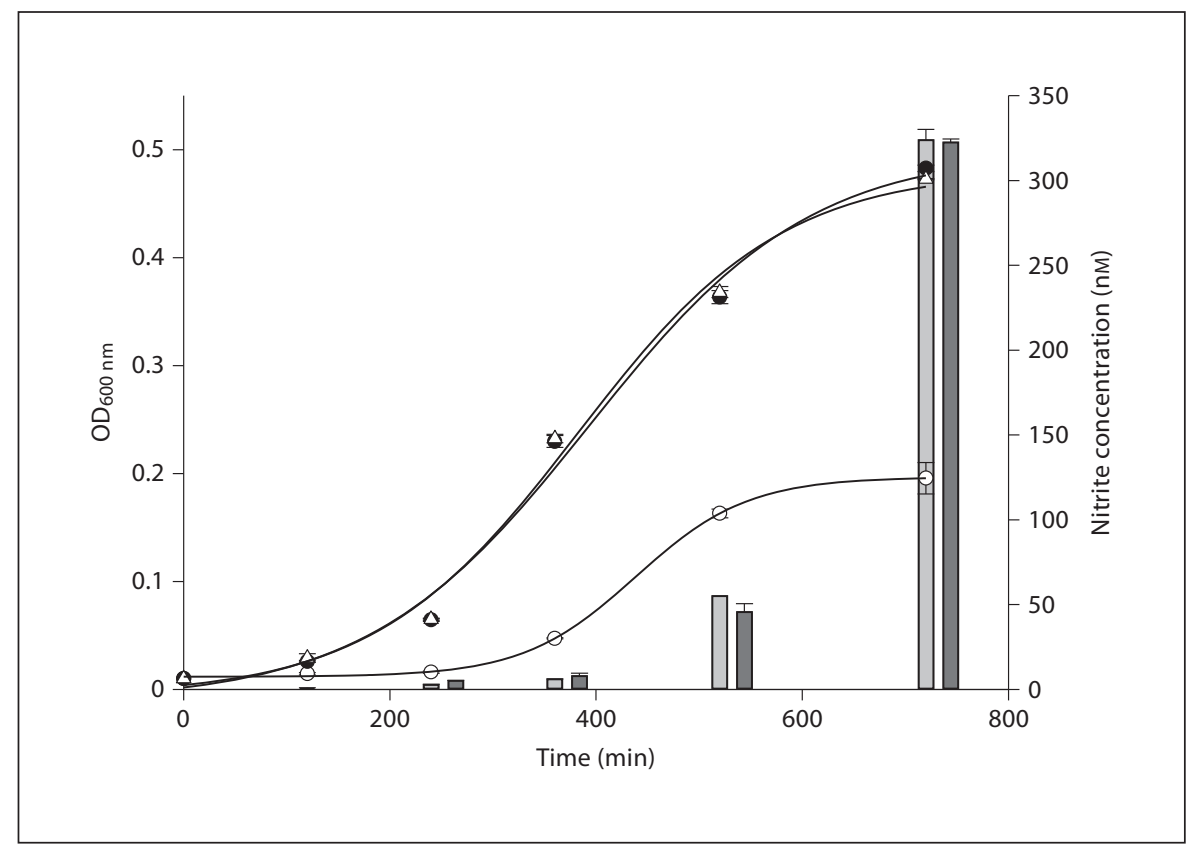

or fused dimeric TatC variant was present, and the levels of nitrite produced (the product of nitrate reduction) were also indistinguishable between the strain harbouring monomeric and fused dimeric TatC (fig. 2). These results were also backed up by the observations (data not shown) that the TatC dimer could support aerobic growth on LB medium containing 2\% SDS (inactivation of the E. coli Tat machinery results in a sensitivity to growth in the presence of SDS due to an inability to export the cell wall amidases AmiA and AmiC [Ize et al., 2003]).

Since non-native proteins can be targets for proteolysis, we next assessed the stability of the TatC fusion protein in whole cell samples. As shown in figure 1c, a single cross-reacting band is visible in the sample containing the fused TatC dimer migrating close to the expected position for a dimeric TatC species [Punginelli et al., 2007]. Thus, we can conclude that a dimeric form of TatC is functional and stable. These findings support previous genetic evidence for a functional multimer of TatC, where certain inactive alleles of tat $C$ could cross-complement each other [Buchanan et al., 2002], and is consistent with biochemical evidence that some cysteine-substituted TatC proteins can form crosslinked dimers [Punginelli et al., 2007]. The simplest conclusion supported by these findings is that the TatBC complex contains an even number of TatC (and therefore presumably also TatB) subunits.

A Fused TatC Dimer is Functional

\section{Only One TatC Unit in the Fused TatC Dimer Needs to Be Active to Support Tat Transport Activity}

The results from the previous section strongly suggest that a TatC dimer acts as a functional unit during Tat transport. To probe whether both constituent monomers within the TatC dimer are required for function, we introduced the inactivating F94A point mutation into either the first or second TatC unit in the fused dimer, or into both halves of the dimer, using standard PCR methods [Buchanan et al., 2002]. The precise function of TatC F94 is not known, although evidence points to a role in the recognition of twin arginine signal peptides by TatC. For example, it has been shown that TatBC complexes containing the monomeric TatC F94A variant are unable to cross-link to substrate precursors containing a photoactivatable amino acid located close to the twin arginine motif in the signal peptide [Holzapfel et al., 2007], and serine substitution at this position facilitates the recognition of variant signal peptides containing a normally inactive twin lysine motif [Strauch and Georgiou, 2007].

Previous studies have indicated that the F94A substitution is one of the few point mutations in TatC that completely inactivates the protein [Barrett et al., 2005; Buchanan et al., 2002; Holzapfel et al., 2007] and in agreement with this a fused TatC dimer where both units harboured the F94A amino acid substitution was unable 


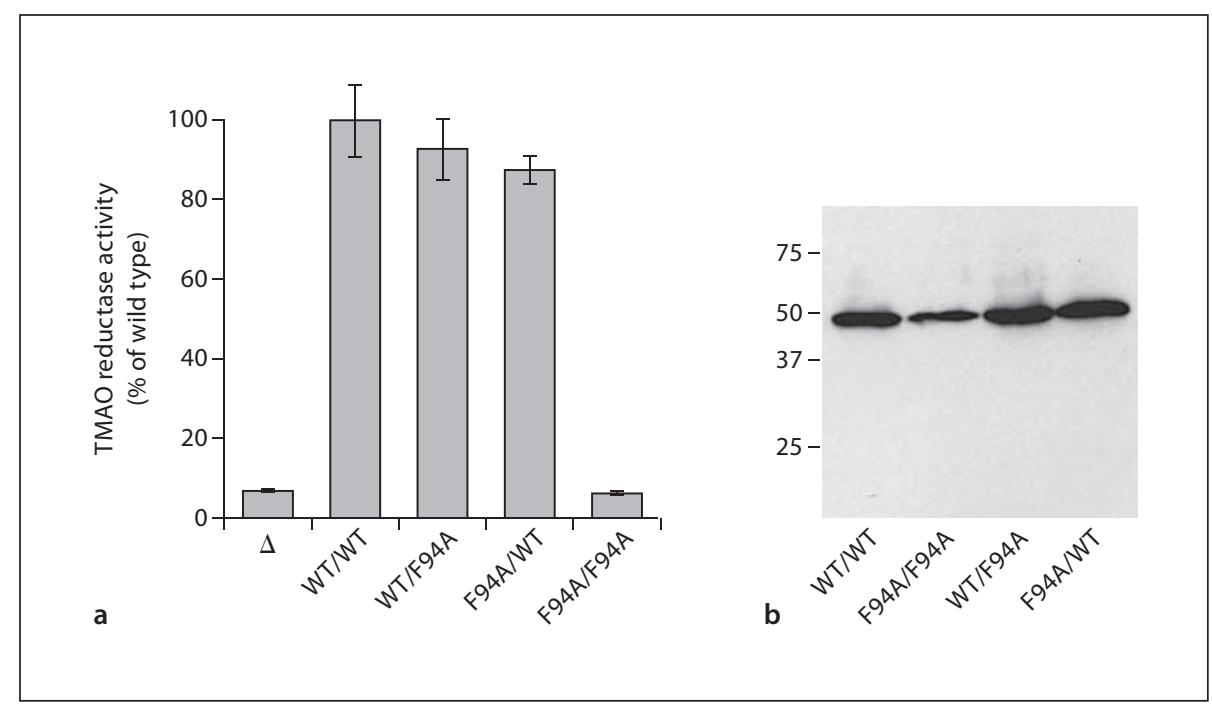

Fig. 3. A fused TatC dimer carrying an inactivating point mutation in one of the TatC units is active. The tatC F94A codon substitution was introduced separately into the pLitmus-TatC-starter and pLitmus-TatC-buildblock plasmids using the QuikChange site-directed mutagenesis method (Stratagene) and the oligonucleotide pairs ATCAGGTGTGGGCAGCAATCGCCCCAGCGCT and AGCGCTGGGGCGATTGCTGCCCACACCTGAT to give pLitmus-TatCF94A-starter and pLitmus-TatCF94A-buildblock, respectively. These constructs were then used to assemble plasmids producing three different fused dimeric TatC variants where either or both TatC units contained the F94A substitution using the cloning strategy described in figure 1. a TMAO reductase activities were measured from the periplasmic fraction of the tat $A B C D E$ deletion strain DADE-P carrying either empty pQE60 vector $(\Delta)$ or a plasmid producing TatA, TatB along with fused dimers of TatC, where both TatC units were wild type (WT/WT), one of the two TatC units harboured the F94A amino acid substitution (F94A/WT and WT/F94A) or both TatC units harboured the inactivating point mutation (F94A/F94A), as indicated. 100\% activity is that determined for DADE-P harbouring the WT/WT TatC dimer and the error bars represent the standard error of the mean $(n=3)$. $\mathbf{b}$ Western blot analysis of whole cell samples from a (approximately $2 \times 10^{7}$ cells loaded per lane). Samples were separated by SDS PAGE (10\% acrylamide) and blotted with antiTatC antiserum. to support any detectable Tat transport activity. Thus, negligible TMAO reductase activity could be detected in the periplasmic fraction of a strain producing this TatC variant (fig. 3a), and the fusion protein was unable to support growth in the presence of SDS or with TMAO as sole electron acceptor (which is a consequence of the inability to export either TMAO or dimethylsulphoxide (DMSO) reductases; growth data not shown).

However, when the fused dimer of TatC carried only one inactivating F94A mutation, the Tat system appeared to show wild type activity, since the periplasmic TMAO reductase activity from strains producing either of these two variant proteins was indistinguishable from that seen for the fused dimer of wild-type TatC (fig. 3a). This was true regardless of whether the functional TatC was the first or second unit of the fused dimer. As shown in figure $3 \mathrm{~b}$, each of the dimeric TatC species was completely stable in vivo, ruling out the possibility that activity arose from $\mathrm{Tat} C$ proteins that had been degraded to free mono- mers. These results therefore confirm that only one of the TatC units in the core dimer needs to be functional to support an active Tat system.

Recent biochemical and structural analysis of the E. coli TatBC complex indicates that it harbours at least two substrate-binding sites that from electron microscopy analysis of TatBC-SufI complexes are always located adjacently [Tarry et al., 2009]. The orthologous complex from plant thylakoids has also been shown to bind multiple precursors, presumably at several adjacent sites, which are collectively transported [Ma and Cline, 2010]. However, the findings here might suggest that adjacent functional receptor sites are not an obligate requirement for operation of the E. coli Tat pathway since inactivating one of the units in the fused TatC dimer did not appear to affect operation of the Tat pathway. An alternative explanation that we cannot rule out is that the dimeric units of TatC are arranged head-to-head such that active TatC units from two neighbouring dimers are positioned next 


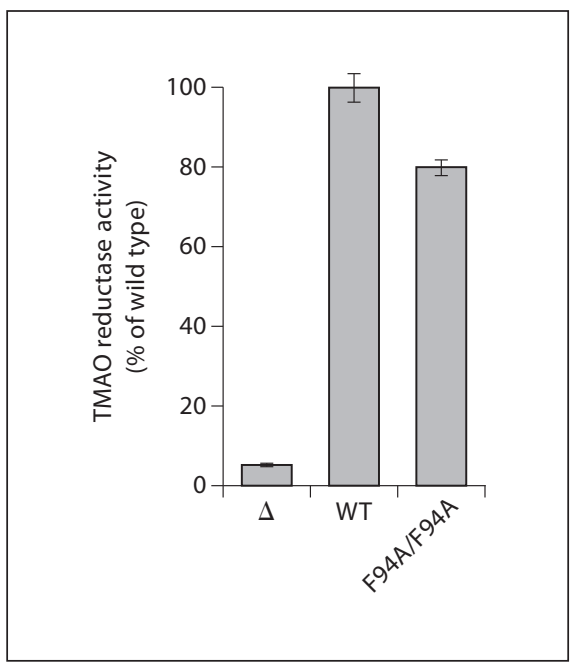

Fig. 4. A fused TatC dimer carrying inactivating point mutations in each TatC unit does not show dominance. TMAO reductase activities were measured from the periplasmic fraction of the $t_{a t}{ }^{+}$ strain MC4100-P carrying either empty pQE60 vector (WT) or a plasmid producing TatA, TatB along with fused dimers of TatC, where both Tat $C$ units harboured the inactivating point mutation (F94A/F94A), or from the tatABCDE deletion strain DADE-P carrying empty pQE60 vector $(\Delta)$ as indicated. $100 \%$ activity is that determined for MC4100-P harbouring the empty vector and the error bars represent the standard error of the mean $(\mathrm{n}=$ 3 or 4$)$.

to each other (although such an organisation would only be feasible for an octameric rather than hexameric stoichiometry).

\section{The Inactive TatC Dimer Containing Two F94A Amino Acid Substitutions Does Not Show Genetic Dominance}

It has previously been shown that the inactive F94A TatC variant does not interfere with the function of wildtype $\mathrm{Tat} C$, i.e. the mutant allele does not show genetic dominance [Buchanan et al., 2002]. The results presented above may provide an explanation for this observation, since it is clear that only one of the TatC proteins needs to be functional for any pair of TatCs in the TatBC complex. We therefore sought to test whether a TatC in which both $\mathrm{Tat} C$ units in the fused dimer were inactivated by the F94A substitution could disrupt the activity of native TatC. To this end, the plasmid-encoded inactive TatC variant was produced in a strain that was wild type for all chromosomal tat genes and the activity of TMAO reduc- tase was determined from the periplasmic fraction of the cell. However, despite the fact that this variant completely inactivated Tat transport when it was the only form of TatC, as shown in figure 4, the inactive fused dimer of TatC did not greatly reduce the export of TMAO reductase, and therefore we conclude that it does not apparently disrupt the function of native TatC within the TatBC complex.

Taken together, these observations suggest that the dimers of TatC function as discrete units and that it is not necessary for all of the dimers within a TatBC receptor complex to be active. This is in accord with the observations of Tarry et al. [2009] who observed only one or two SufI molecules bound to each TatBC complex. In the experiments described here, it is likely that the plasmid-produced inactive TatC dimer is in considerable excess (around 40-fold over native, chromosomal, levels of TatC from this plasmid expression system [Punginelli, 2005]), and therefore these observations suggest that only very few Tat $B C$ units in any one receptor need to be functional to support wild type levels of Tat transport activity.

\section{Larger Fused Oligomers of TatC Support Tat Transport Activity but Are Subject to in vivo Degradation}

Since the genetic fusion approach described above provided convincing evidence that a covalent TatC dimer was functional, we sought to use the same technology to construct larger oligomeric fusions of TatC. Using the strategy outlined in figure 1a, we extended the number of repeating TatC units sequentially, up to a tandem fused hexameric TatC. We then tested the ability of the fused TatC oligomers to support Tat-dependent protein transport, again by measuring the activity of TMAO reductase from periplasmic fractions. As shown in figure $5 \mathrm{a}$, it is apparent that each of the TatC fused oligomers had Tat transport activity. Furthermore, each of the TatC fusions tested could support anaerobic growth on minimal media containing TMAO as sole electron acceptor and on LB medium containing 2\% SDS (data not shown).

To assess the stability of the fused oligomers, we carried out Western blotting on the same whole cell samples that we subsequently fractionated for the TMAO reductase assays. As shown in figure 5b, whilst the fused dimer of TatC was completely stable, all of the larger fusion proteins showed degradation to smaller forms. 


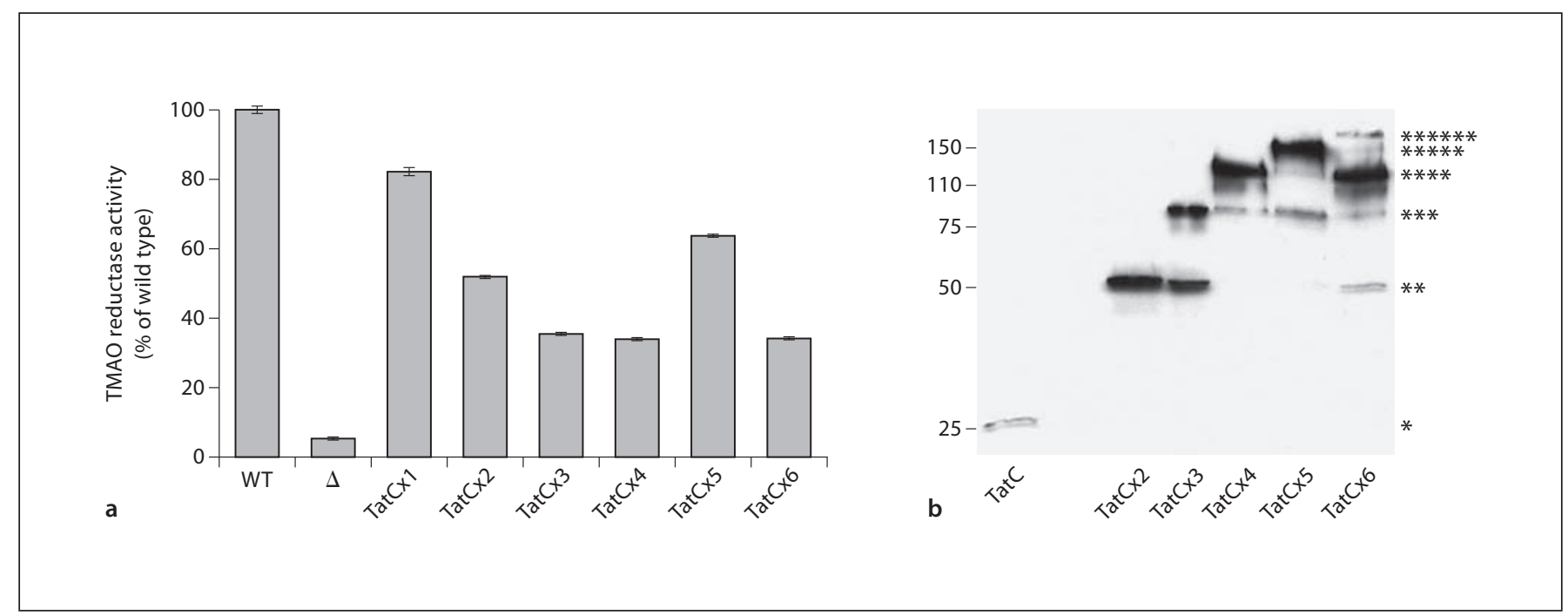

Fig. 5. TatC fusion proteins that are larger than dimers support Tat transport activity but are prone to degradation. a TMAO reductase activities were measured from the periplasmic fraction of the tat $^{+}$strain MC4100-P (WT), the tat $A B C D E$ deletion strain DADE-P carrying either empty $\mathrm{pQE} 60$ vector $(\Delta)$ or a plasmid producing Tat $\mathrm{A}$, TatB along with $\mathrm{C}$-terminally histagged variants of TatC proteins comprising otherwise native TatC or fusion proteins containing between 2 and 6 TatC units, as indicated. $100 \%$ activity is that determined for MC4100-P, and the error bars represent the standard error of the mean $(n=3$ or 4$)$. $\mathbf{b}$ Western blot

Thus, whilst Tat transport activity was noted for strains producing these fusions, we cannot rule out that the activity arose due to the release of smaller degradation products rather than being associated with the fulllength fusion protein.

Whilst the instability of the TatC fusion proteins may be due to the fact that they are overproduced, it occurred to us that the degradation of the TatC fusions might also be related to protein transport by the Tat machinery. To assess this, we deleted the tat $A$ gene from each of these Tat $C$ fusion-encoding clones (by subcloning of the $\Delta$ tat $A$ allele from pFAT75 $\Delta$ A [McDevitt et al., 2005] as an EcoRI-EcoRV fragment) and examined the stability of the TatC proteins encoded on these constructs in strain DADE, which is deleted for all chromosomal tat genes. However, in this case we also saw significant degradation of the TatC fusions (data not shown). Thus, it appears that TatC fusions which are larger than a fused dimer are inherently unstable and that their degradation is not related to the activity of the Tat machinery.

In conclusion, the results presented here support the idea that $E$. coli $\mathrm{Tat} C$ is a functional dimer, and would analysis of whole cell samples of strain DADE-P carrying plasmids producing Tat $\mathrm{A}$, TatB along with $\mathrm{C}$-terminally histagged variants of monomeric or fused multimeric TatC as indicated (approximately $2 \times 10^{7}$ cells loaded per lane) grown under identical conditions to a. Samples were separated by SDS PAGE (10\% acrylamide) and blotted with anti-TatC antiserum. The sizes of molecular weight standards in $\mathrm{kDa}$ are indicated to the left of each blot, and the asterisks indicate the migration positions of TatC monomer $\left(^{*}\right)$, dimer $\left(^{* *}\right)$, trimer $\left(^{* * *}\right)$, tetramer $\left({ }^{* * *}\right)$, pentamer $(* * * *)$ and hexamer $(* * * * *)$.

therefore indicate that the TatBC complex contains even numbers of subunits. The instability of larger fused repeats of TatC does not allow conclusions to be drawn about higher-order arrangement of the TatC. However, it is possible that additional functional arrangements such as trimers, tetramers or hexamers of TatC might also exist, at least transiently, during Tat transport. Determining the precise stoichiometry of the TatBC complex and indeed whether this might change during protein transport will require further experimentation.

\section{Acknowledgements}

This work is supported by the UK Medical Research Council. We thank Sabine Grahl and Frank Sargent for kindly providing us with strain SG1100 deltaTat::Apra and Prof. Frank Sargent for helpful discussion. 


\section{References}

-Alami M, Luke I, Deitermann S, Eisner G, Koch HG, Brunner J, Muller M: Differential interactions between a twin-arginine signal peptide and its translocase in Escherichia coli. Mol Cell 2003;12:937-946.

-Alami M, Trescher D, Wu LF, Muller M: Separate analysis of twin-arginine translocation (Tat)-specific membrane binding and translocation in Escherichia coli. J Biol Chem 2002;277:20499-20503.

-Barrett CM, Mangels D, Robinson C: Mutations in subunits of the Escherichia coli twin-arginine translocase block function via differing effects on translocation activity or tat complex structure. J Mol Biol 2005;347:453-463.

Berks BC: A common export pathway for proteins binding complex redox cofactors? Mol Microbiol 1996;22:393-404.

Bogsch EG, Sargent F, Stanley NR, Berks BC, Robinson C, Palmer T: An essential component of a novel bacterial protein export system with homologues in plastids and mitochondria. J Biol Chem 1998;273:1800318006.

Bolhuis A, Mathers JE, Thomas JD, Barrett CM, Robinson C: TatB and tatC form a functional and structural unit of the twin-arginine translocase from Escherichia coli. J Biol Chem 2001;276:20213-20219.

-Buchanan G, de Leeuw E, Stanley NR, Wexler M, Berks BC, Sargent F, Palmer T: Functional complexity of the twin-arginine translocase TatC component revealed by site-directed mutagenesis. Mol Microbiol 2002;43:14571470 .

Cline K, Theg SM: The Sec and Tat protein translocation pathways in chloroplasts; in Dalbey RE, Koehler CM, Tamanoi F (ed): Molecular Machines Involved in Protein Transport Across Cellular Membranes. London, Elsevier, 2007, vol XXV, pp 463-492.

Dabney-Smith C, Mori H, Cline K: Oligomers of Tha4 organize at the thylakoid Tat translocase during protein transport. J Biol Chem 2006;281:5476-5483.

de Leeuw E, Granjon T, Porcelli I, Alami M, Carr SB, Muller M, Sargent F, Palmer T, Berks BC: Oligomeric properties and signal peptide binding by Escherichia coli Tat protein transport complexes. J Mol Biol 2002;322:11351146.

Driessen AJ, Nouwen N: Protein translocation across the bacterial cytoplasmic membrane. Annu Rev Biochem 2008;77:643-667.

-Gerard F, Cline K: Efficient twin arginine translocation (Tat) pathway transport of a precursor protein covalently anchored to its initial cpTatc binding site. J Biol Chem 2006;281: 6130-6135.
Gohlke U, Pullan L, McDevitt CA, Porcelli I, de Leeuw E, Palmer T, Saibil HR, Berks BC: The TatA component of the twin-arginine protein transport system forms channel complexes of variable diameter. Proc Natl Acad Sci USA 2005;102:10482-10486.

Holzapfel E, Eisner G, Alami M, Barrett CM, Buchanan G, Luke I, Betton JM, Robinson C, Palmer T, Moser M, Muller M: The entire Nterminal half of TatC is involved in twin-arginine precursor binding. Biochemistry 2007;46:2892-2898.

Ize B, Stanley NR, Buchanan G, Palmer T: Role of the Escherichia coli Tat pathway in outer membrane integrity. Mol Microbiol 2003;48: 1183-1193.

Jones PC, Fillingame RH: Genetic fusions of subunit $\mathrm{c}$ in the $\mathrm{F}_{0}$ sector of $\mathrm{H}^{+}$-transporting ATP synthase. Functional dimers and trimers and determination of stoichiometry by cross-linking analysis. J Biol Chem 1998;273: 29701-29705.

Leake MC, Greene NP, Godun RM, Granjon T, Buchanan G, Chen S, Berry RM, Palmer T, Berks BC: Variable stoichiometry of the TatA component of the twin-arginine protein transport system observed by in vivo singlemolecule imaging. Proc Natl Acad Sci USA 2008;105:15376-15381.

Lee PA, Orriss GL, Buchanan G, Greene NP, Bond PJ, Punginelli C, Jack RL, Sansom MS, Berks BC, Palmer T: Cysteine-scanning mutagenesis and disulfide mapping studies of the conserved domain of the twin-arginine translocase TatB component. J Biol Chem 2006;281:34072-34085.

Lester RL, DeMoss JA: Effects of molybdate and selenite on formate and nitrate metabolism in Escherichia coli. J Bacteriol 1971;105: 1006-1014.

Ma X, Cline K: Multiple precursor proteins bind individual tat receptor complexes and are collectively transported. EMBO J 2010;29: 1477-1488.

-Maurer C, Panahandeh S, Jungkamp AC, Moser M, Müller M: TatB functions as an oligomeric binding site for folded Tat precursor proteins. Mol Biol Cell 2010;21:4151-4161.

McDevitt CA, Hicks MG, Palmer T, Berks BC: Characterisation of Tat protein transport complexes carrying inactivating mutations. Biochem Biophys Res Comm 2005;329:693698.

Mori H, Cline K: A twin arginine signal peptide and the ph gradient trigger reversible assembly of the thylakoid [delta]pH/Tat translocase. J Cell Biol 2002;157:205-210.

Mori H, Summer EJ, Cline K: Chloroplast TatC plays a direct role in thylakoid (delta)pH-dependent protein transport. FEBS Letts 2001; 501:65-68.

Muller M: Twin-arginine-specific protein export in Escherichia coli. Res Microbiol 2005; 156:131-136.
Oates J, Mathers J, Mangels D, Kuhlbrandt W, Robinson C, Model K: Consensus structural features of purified bacterial TatABC complexes. J Mol Biol 2003;330:277-286.

Palmer T, Sargent F, and Berks BC: The Tat protein export pathway; in Böck A, Curtiss III R, Kaper JB, Karp PD, Neidhardt FC, Nyström T, Slauch JM, Squires CL, Ussery D (eds): EcoSal - Escherichia coli and Salmonella: Cellular and Molecular Biology. Washington, ASM Press, 2010.

Punginelli C: The Escherichia coli Tat protein translocase and its substrates; thesis, University of East Anglia, 2005.

Punginelli C, Maldonado B, Grahl S, Jack R, Alami M, Schroder J, Berks BC, Palmer T: Cysteine scanning mutagenesis and topological mapping of the Escherichia coli twin-arginine translocase Tatc component. J Bacteriol 2007;189:5482-5494.

Richter S, Bruser T: Targeting of unfolded PhoA to the Tat translocon of Escherichia coli. J Biol Chem 2005;280:42723-42730.

-Sargent F, Bogsch EG, Stanley NR, Wexler M, Robinson C, Berks BC, Palmer T: Overlapping functions of components of a bacterial Sec-independent protein export pathway. EMBO J 1998; 17:3640-3650.

-Sargent F, Stanley NR, Berks BC, Palmer T: Secindependent protein translocation in Escherichia coli. A distinct and pivotal role for the TatB protein. J Biol Chem 1999;274:3607336082.

Settles AM, Yonetani A, Baron A, Bush DR, Cline K, Martienssen R: Sec-independent protein translocation by the maize Hcf106 protein. Science 1997;278:1467-1470.

$\checkmark$ Silvestro A, Pommier J, Giordano G: The inducible trimethylamine- $N$-oxide reductase of Escherichia coli K12: biochemical and immunological studies. Biochim Biophys Acta 1988;954:1-13.

Stanley NR, Palmer T, Berks BC: The twin arginine consensus motif of Tat signal peptides is involved in Sec-independent protein targeting in Escherichia coli. J Biol Chem 2000; 275:11591-11596.

-Strauch EM, Georgiou G: Escherichia coli TatC mutations that suppress defective twin-arginine transporter signal peptides. J Mol Biol 2007;374:283-291.

- Tarry MJ, Schafer E, Chen S, Buchanan G, Greene NP, Lea SM, Palmer T, Saibil HR, Berks BC: Structural analysis of substrate binding by the TatBC component of the twin-arginine protein transport system. Proc Natil Acad Sci U S A 2009;106:1328413289.

Weiner JH, Bilous PT, Shaw GM, Lubitz SP, Frost L, Thomas GH, Cole JA, Turner RJ: A novel and ubiquitous system for membrane targeting and secretion of cofactor-containing proteins. Cell 1998;93:93-101. 